\title{
Zinc, Copper and Selenium in Children with Idiopathic Nephrotic Syndrome: Relationship to Parathyroid Hormone \& Proteinuria
}

\author{
Gamila S.M. Elsaeed ${ }^{1}$, Fatina Fadel $^{2}$, Marwa M. El-Sonbaty ${ }^{3}$, Hanaa Wafaey ${ }^{1}$, \\ Mahmoud A. Abdel-Monem ${ }^{1}$, Inas Abdelhamid ${ }^{4}$, Yosra A. Fahmy ${ }^{2}$, Eman A. \\ Elghoroury $^{5}$ and Manal F Elshamaa ${ }^{4}$
}

\author{
${ }^{I}$ Medical Biochemistry Department, National Research Centre, 33 El-Buhouth St., 12622 Dokki, Giza, \\ Egypt. \\ ${ }^{2}$ Pediatrics Department, Faculty of Medicine, Cairo University, Egypt. \\ ${ }^{3}$ Child Health Department, Medical Research Division, National Research Centre, 33 El-Buhouth St., \\ 12622 Dokki, Giza, Egypt. (Affiliation ID: 60014618), Department of Pediatrics, College of Medicine, \\ Taibah University, Madinah, K.S.A. \\ ${ }^{4}$ Pediatrics Department, National Research Centre, 33 El-Buhouth St., 12622 Dokki, Giza, Egypt. \\ ${ }^{5}$ Clinical Pathology Department, National Research Centre, 33 El-Buhouth St., 12622 Dokki, Giza, \\ Egypt.
}

Received: 10 June 2020 / Accepted 15 July 2020 / Publication date: 30 July 2020

\begin{abstract}
Background: Trace elements had a vital role in metabolism and usually found in blood attached to proteins. The aim was to detect the status of selenium $(\mathrm{Se})$, zinc $(\mathrm{Zn})$, and copper $(\mathrm{Cu})$ in children with idiopathic nephrotic syndrome (NS) and to correlate them with vitamin D (Vit. D), parathyroid hormone (PTH) and intact PTH (iPTH) in this patients group. Method: 30 NS patients and 24 agematched healthy controls were included in the study. The $\mathrm{Se}, \mathrm{Zn}$ and $\mathrm{Cu}$ level in serum were measured by the inductively coupled plasma atomic emission spectroscopy (ICP-OES), while, Vit D, PTH and iPTH were measured by ELIZA. Results: The serum levels of $\mathrm{Zn}, \mathrm{Se}, \mathrm{Cu}$, Vit .D and PTH and iPTH were significantly lower in patients (for all $p<0.005$ ) than in healthy controls. A significant negative correlation was found between serum levels of PTH and $\mathrm{Zn}$ levels. Serum $\mathrm{Zn}$ and $\mathrm{Cu}$ were positively correlated with urinary albumin/creatinine ratio Conclusion: PTH may have a role in the pathogenesis of $\mathrm{Zn}$ deficiency. Serum $\mathrm{Zn}$ and $\mathrm{Cu}$ levels were favorably associated with proteinuria in NS patients. Supplementation with Zn, Se and Cu may be of benefit in children with idiopathic NS.
\end{abstract}

Keywords: Nephrotic syndrome, Zinc, Copper, Selenium, Vitamin D, Parathyroid hormone, Intact parathyroid hormone, Children

\section{Introduction}

Nephrotic syndrome (NS) is a common pediatric kidney disease; it is characterized by heavy proteinuria (Bakkaloglu and Schaefer, 2011), hypoalbuminemia, edema, and hypercholesterolemia (Hossain et al., 2016; El-Saeed et al., 2018). Disturbances of mineral metabolism, such as deficiency of Zinc (Zn) (Tulpar et al., 2014; Haque et al., 2017 and Manser, 1989), copper (Cu), (Tulpar et al., 2014; Haque et al., 2017), Selenium (Se) (Tulpar et al., 2014), parathyroid hormone (PTH) (Souberbielle et al., 2006) and vitamin D (Vit D) (Joyce et al., 2020) is a common finding in children with NS. These are mainly caused by the loss of a variety of plasma proteins and minerals in the urine in addition to steroid therapy. Early recognition and treatment of these problems, could prevent growth retardation and renal osteodystrophy that affects children with NS (Joyce et al., 2020).

Trace elements play a vital role in several metabolic processes. Their deficiency can cause many problems especially during growth and development periods. $\mathrm{Zn}$ is an important element which is included in the structure of nearly 120 enzymes (Tulpar et al., 2014), it is present in nearly all body tissues. It is a highly protein bound mineral, $50 \%$ of plasma $\mathrm{Zn}$ is bound to albumin and the rest is bound to other plasma proteins (Haque et al., 2017). Childhood growth retardation, impaired immune

Corresponding Author: Marwa M. El-Sonbaty, Child Health Department, Medical Research Division, National Research Centre, 33 El-Buhouth St., 12622 Dokki, Giza, Egypt. (Affiliation ID: 60014618), Department of Pediatrics, College of Medicine, Taibah University, Madinah, K.S.A. E-mail: elsonbatymostafa@yahoo.com 
function, increased rate of infections, possibly increased rates of mortality as a result of infections and abnormal neurobehavioral development are from the functional consequences of $\mathrm{Zn}$ deficiency (Haque et al., 2017).

Selenium (Se) is also an important element which has a vital function in gene transcription, antioxidant system, thyroid hormone function, cardiomyopathy and immune system (Tulpar et al., 2014). Copper (CU) deficiency has been associated with some forms of anemia (Manser, 1989).

The most commonly used assay for measuring PTH levels now in clinical practice is the intact PTH assay. Although there is a good correlation between the intact and bioactive PTH assays in patients with chronic kidney disease (CKD), mean intact PTH assay are 30-50\% higher than PTH levels ( Souberbielle et al., 2006). Accumulation of non-(1-84) PTH fragments found seldomely by the intact PTH assay may be the cause. Vit D is a fat-soluble vitamin that has a great role in regulation of hormones like insulin, renin and PTH production and elevated levels of iPTH (Joyce et al., 2020). A small number of researches investigated the status of trace elements in NS in children and there are great differences in their results (Tulpar et al., 2014; Hamik et al., 2019; Kumar et al., 2017).

The aim of the study was to investigate the status of the essential elements $\mathrm{Zn}, \mathrm{Se}$ and $\mathrm{Cu}$ in children with NS and to correlate with Vit. D, PTH and iPTH levels in this patient group.

\section{Methods}

\section{Patients}

This study included 30 children with NS recruited from Pediatric Nephrology Clinic, Children`s Hospital, Cairo university and 24 healthy children as control subjects with no history of renal diseases were recruited from the pediatric clinic of Centre of Excellence, National Research Centre, Cairo, Egypt. They were age and sex, matched. Inclusion criteria of NS children were the presence of nephrotic-range proteinuria (protein excretion of more than $40 \mathrm{mg} / \mathrm{m} 2 / \mathrm{h}$ ), edema, hypoalbuminemia (serum albumin $<3 \mathrm{gm} / \mathrm{dl}$ ), and hypercholesterolemia (serum cholesterol $>200 \mathrm{mg} / \mathrm{dl}$ ) at assessment. Each NS patient was subjected to full medical history taking focusing on frequency of relapses, response to steroid therapy, and need of other immunosuppressive or cytotoxic drugs. Physical examination of all included cases and control children focusing on body mass index (BMI) calculated by the formula $\left[\mathrm{BMI}=\right.$ weight $(\mathrm{kg}) /$ height $\left.\left(\mathrm{m}^{2}\right)\right]$, and blood pressure measurement. Nephrotic syndrome cases with impaired kidney function and those with ESRD on dialysis were excluded from the current study. Ethical considerations: Informed consent was obtained from included children`s guardians. The study had been approved by the Ethical committee of National Research Centre (NRC), Egypt.

\section{Collection and processing of samples}

Approximately $5 \mathrm{ml}$ of blood was collected from all the study subjects in appropriate tubes for subsequent laboratory analyses. Serum was isolated by centrifugation and was used for the biochemical analyses.

Laboratory investigation were done for all cases and controls including complete blood picture using Coulter Counter T890 (Coulter Counter, Harpenden, UK) and serum levels of albumin, creatinine and cholesterol, using the automated clinical chemistry analyzer (Olympus AU 400 analyzer).

\section{Assay of PTH, iPTH and 25-hydroxyvitamin D in serum}

Enzyme linked immunosorbent assay (ELISA) was used to measure the concentration of serum PTH and iPTH (DRG International, Inc., (USA). (EIA-3645); and 25(OH) $\mathrm{D}_{3}$ (total), (DRG Diagnostics GmbH, (Germany, (EIA-5396)).

\section{Assay of serum $\mathrm{Zn}, \mathrm{Cu}$ and Se levels}

Determination of $\mathrm{Se}, \mathrm{Cu}$ and $\mathrm{Zn}$ ions using the Agilent 5100 Synchronous Vertical Dual View (SVDV) by the inductively coupled plasma atomic emission spectroscopy (ICP-OES), with Agilent Vapor Generation Accessory VGA77. All samples were digested to have acceptable matrix for measuring of $\mathrm{Se}, \mathrm{Zn}$, and $\mathrm{Cu}$ ions and to provide acceptable and consistent recovery compatible with the analytical method of Kumar et al. (2017) for each series of measurements intensity calibration 
curve was constructed composed of a blank and three or more standards from Merck Company (Germany).Accuracy and precision of the $\mathrm{Se}, \mathrm{Zn}$ and $\mathrm{Cu}$ ions measurements were confirmed using external reference standards from Merck, and standard reference material and quality control sample from National Institute of Standards and Technology (NIST), were used to confirm the instrument reading.

\section{Statistical analysis}

Data were coded and entered using the Statistical package for social science (SPSS) program version 16. It was used for analysis of data which was represented as mean \pm SD. Student's t-test for quantitative independent variables was used for analysis of difference between two groups. Correlation between quantitative variables was done using Pearson's bivariate test. In all tests $\mathrm{P}<0.05$ was considered statistically significant.

\section{Results}

Patients were 16 males and 14 females, their age ranges between 4 and 15 years. All NS children were on steroids. Steroid resistant NS (failed of response after 4 weeks of daily oral steroid therapy of $60 \mathrm{mg} / \mathrm{m} 2$ /day followed by three pulses of methylprednisolone) were in $46 \%$ of cases. Half of the cases were on cytotoxic drugs in addition to steroid therapy (No: 15). Frequent relapsing NS (had two consecutive relapses or two or more relapses in any 6month period) was in 9 patients. Calcium channel blocker was taken by 27 patients.

Clinical characteristics and biochemical indicators of the NS patients and healthy controls were shown in table 1. Serum vitamin D and PTH $(11 . .48 \pm 5.407 \mathrm{ng} / \mathrm{ml}$ vs $27.81 \pm 5.65 \mathrm{ng} / \mathrm{ml}, \mathrm{p}=0.000), 25$. $18 \pm 1.07 \mathrm{pg} / \mathrm{ml}$ vs. $49.67 \pm 2.93 \mathrm{pg} / \mathrm{ml}, \mathrm{p}=0.003$, respectively) levels were significantly lower in NS children than in controls. Serum iPTH, levels was significantly lower in NS children $(21.77 \pm 8.50$ $\mathrm{pg} / \mathrm{ml} \mathrm{vs} 88.69 \pm 39.03 \mathrm{pg} / \mathrm{ml}, \mathrm{p}=0.000$ ) than in controls.

Table 1: General characteristics and biochemical parameters of the studied groups.

\begin{tabular}{|c|c|c|c|}
\hline Parameter & Controls $(\mathrm{N}=24)$ & NS $(\mathbf{N}=30)$ & P-Value \\
\hline Age (years) & $8 \pm 4.51$ & $8.17 \pm 3.41$ & 0.12 \\
\hline Gender: $M / F$ & $12 / 12(50 \% / 50 \%)$ & $16 / 14(53.33 \% / 46.67 \%)$ & 0.22 \\
\hline BMI(kg/m2) & $20.60 \pm 1.44$ & $17.1 \pm 4.8$ & $0.006 * *$ \\
\hline SBP(mmHg) & $95.54 \pm 9.70$ & $98.66 \pm 6.66$ & $0.022 *$ \\
\hline DBP(mmHg) & $61.55 \pm 10.10$ & $64.66 \pm 6.67$ & $0.032 *$ \\
\hline Hemoglobin (g/dL) & $14.07 \pm 0.65$ & $12.14 \pm 1.30$ & $0.001 * *$ \\
\hline $\operatorname{Albumin}(\mathrm{g} / \mathrm{dl})$ & $4.81 \pm 0.31$ & $2.94 \pm 1.02$ & $0.000 * *$ \\
\hline Cholesterol (mg/dL) & $173.29 \pm 14.20$ & $372.14 \pm 73.15$ & $0.001 * *$ \\
\hline Urinary ACR & $1.90 \pm 0.2$ & $3.97 \pm 1.5$ & $0.000 * *$ \\
\hline PTH $(\mathbf{p g} / \mathrm{mL})$ & $49.67 \pm 2.93$ & $25.18 \pm 1.07$ & $0.003 * *$ \\
\hline iPTH $(\mathrm{pg} / \mathrm{mL})$ & $88.69 \pm 39.03$ & $21.77 \pm 8.50$ & $0.000 * *$ \\
\hline Vit D (ng/mL) & $27.81 \pm 5.65$ & $11.48 \pm 5.40$ & $0.000 * *$ \\
\hline $\operatorname{Se}(\mu \mathrm{g} / \mathrm{gm})$ & $635.00 \pm 24.63$ & $454.28 \pm 41.74$ & $0.0001 * *$ \\
\hline $\mathrm{Cu}(\mu \mathrm{g} / \mathrm{gm})$ & $482.86 \pm 30.6$ & $426.21 \pm 26.07$ & $0.000 * *$ \\
\hline $\mathrm{Zn}(\boldsymbol{\mu g} / \mathbf{g m})$ & $452.36 \pm 287.33$ & $346.14 \pm 51.95$ & $0.002 * *$ \\
\hline Zn/ Alb ratio & 0.941 & 1.193 & $0.0001 * *$ \\
\hline
\end{tabular}

BMI (body mass index), SBP (systolic blood pressure), DBP (diastolic blood pressure), ACR (Albumin/ creatinine ratio). Vit D (Vitamin D), PTH (parathyroid hormone), iPTH (intact parathyroid hormone). All data are represented as mean $\pm \mathrm{SD}$ or $\%$ as applicable. $* \mathrm{P}$ value $<0.05$ or $* * \mathrm{P}<0.01$ was considered significant.

Trace elements, $\mathrm{Zn}, \mathrm{Cu}$ and Se levels were significantly lower in NS children than in controls, $(346.14 \pm 51.95 \mu \mathrm{g} / \mathrm{gm}$ vs.452.36 $\pm 287.33 \mu \mathrm{g} / \mathrm{gm}, \mathrm{p}=0.002),(426.21 \pm 26.07 \mu \mathrm{g} / \mathrm{gm}$ vs. $482.86 \pm 30.6$ $\mu \mathrm{g} / \mathrm{gm}, \mathrm{p}=0.000),(454.28 \pm 41.74 \mu \mathrm{g} / \mathrm{gm}$ vs. $635.00 \pm 24.63 \mu \mathrm{g} / \mathrm{gm}, \mathrm{p}=0.0001)$. Zinc/Albumin ratio $(\mathrm{Zn} / \mathrm{Alb})$ was significantly higher in NS patients than in healthy controls $(1.193$ vs. $0.941, \mathrm{p}=0.0001)$. Hemoglobin $(\mathrm{Hb})$ levels, $(12.14 \pm 1.30 \mathrm{gm} / \mathrm{dl}$ vs. $14.07 \pm 0.65 \mathrm{gm} / \mathrm{dl}, \mathrm{p}=0.001)$, serum cholesterol levels $(372.14 \pm 73.15 \mathrm{mg} / \mathrm{dl}$ vs. $173.29 \mathrm{mg} / \mathrm{dl} \pm 14.20, \mathrm{p}=0.001)$ and urinary albumin/creatinine ratio (ACR) $(3.97 \pm 1.5$ vs. $1.90 \pm 0.2, \mathrm{p}<0.000)$ showed highly significant difference between NS children group and healthy controls. 
Serum $\mathrm{Cu}$ and $\mathrm{Zn}$ levels were correlated positively with ACR ( $\mathrm{r}=0.620, \mathrm{p}=0.018$ \& $\mathrm{r}=0.617$, $\mathrm{p}=0.019$ respectively). There was a significant negative correlation between serum PTH and Zn levels $(\mathrm{r}=-0.598, \mathrm{p}=0.024)$ (Table 2). A significant positive correlation was detected between serum Vit $\mathrm{D}$ and cholesterol levels $(\mathrm{r}=0.592, \mathrm{p}=0.026)$ in NS. A significant positive correlation was found between serum $\mathrm{Cu}$ and $\mathrm{Zn}$ levels $(\mathrm{r}=0.931, \mathrm{p}=0.00)$ and a significant negative correlation was found between serum iPTH levels and hemoglobin levels $(r=-0.559, \mathrm{p}=0.038)$.

Table 2: Pearson's Correlations between SE, $\mathrm{Cu}$ and $\mathrm{Zn}$ and other laboratory parameters in children with NS

\begin{tabular}{lcccccc}
\hline & $\begin{array}{c}\text { Zn } \\
\text { r }\end{array}$ & p-value & $\begin{array}{c}\text { Cu } \\
\text { r }\end{array}$ & p-value & $\begin{array}{c}\text { Se } \\
\text { r }\end{array}$ & p-value \\
\hline Vit D(ng/ml) & -0.148 & 0.615 & 0.109 & 0.712 & 0.339 & 0.236 \\
PTH(pg/ml) & -0.598 & $0.024^{*}$ & 0.425 & 0.129 & 0.186 & 0.524 \\
iPTH(pg/ml) & -0.074 & 0.802 & -0.043 & 0.884 & 0.062 & 0.833 \\
Hemoglobin(g/dl & -0.154 & 0.600 & -0.114 & 0.697 & 0.082 & 0.780 \\
Cholesterol(mg/dl) & 0.167 & 0.568 & 0.412 & 0.143 & 0.294 & 0.307 \\
Urinary ACR & 0.617 & $0.019 * *$ & 0.620 & $0.018^{* *}$ & -0.018 & 0.952 \\
\hline
\end{tabular}

Vit D (Vitamin D), PTH (parathyroid hormone), iPTH (intact parathyroid hormone), ACR (Albumin/ creatinine ratio). *P value $<0.05$ or $* * \mathbf{P}<0.01$ was considered significant.

\section{Discussion}

In this study, we found that serum $\mathrm{Zn}, \mathrm{Cu}$ and Se levels were deficient in children with NS than in healthy controls. $\mathrm{Zn}$ is needed for many aspects of cellular metabolism. Nearly 100 enzymes need $\mathrm{Zn}$ for their catalytic activity. Cell division, DNA synthesis, Protein formation, wound healing and immune function require $\mathrm{Zn}$. It is also needed for optimum growth and development (NIH, 2020). increased risk of infections, down regulation of type-1 cytokine and relative type-2 cytokine bias may result from low Zn levels (Manser, 1989; Hamik et al., 2019 ; Kumar et al., 2017 and APHA et al., 2017 ). Zinc supplementation may be considered as preventive strategy from infections and relapses in nephrotic syndrome (Sasi et al., 2009). Arun et al. (2009) suggest that either higher dose is required or Zinc deficiency may not be contributing factor for infection and relapses in nephrotic children. Afroze et al. (2014) postulated that restoration of balance with use of $\mathrm{Zn}$ may be the mechanism preventing relapses rather than reduction in infections and thereby relapses.

$\mathrm{Cu}$ is very important for the hematological and neurological systems. Its deficiency can lead to many serious conditions (Wazir and Ghobrial, 2017). Our findings reveled that children with NS have much lower levels of $\mathrm{Se}, \mathrm{Zn}$ and $\mathrm{Cu}$ which can lead to the associated manifestations with those elements deficiency Abnormalities of $\mathrm{Cu}$ and $\mathrm{Zn}$ metabolism are well documented in patients with NS. It is postulated that renal scars could be prevented or reduced by administration of different types of antioxidants (Tulpar et al., 2014).

$\mathrm{Se}$ is an essential trace element for human health. Selenoproteins, which is formed from Se are important for normal health and metabolism. It is important for glutathione peroxidase (GPx), Iodothyronine deiodinases, immune system functioning, cognition and behavior (Shreenath and Dooley, 2020). Previous Egyptian research revealed behavioral problems in children with nephrotic syndrome which can be attributed to mineral and trace element deficiency as Se (Boraey and ElSonbaty, 2011).

A diet, which is deficient in Se resulted in reduction in GPx activity, which in turn reduces antioxidant activity in the tissues. Prednisone can affect absorption and metabolism of Se. Transcriptional regulation of GPx could be affected by Se. Expression of mRNA for the Se-dependent GPx impaired markedly by Se deficiency. During the edematous stage, after prednisone treatment, and in remission; Se exhibit reduced GPx activity. Serum Se level increases with enhanced activity of GPx. at the end of high-dose prednisone treatment. Reduced dose of alternate day prednisone treatment does not affect GPx activity (Fydryk et al., 2003).

Numerous selenocompounds as selenoproteins are important enzymes for maintaining the cellular redox homeostasis. Compromised immune responses resulted from deficiency of Se and selenoproteins (Hiller et al., 2015). Higher urinary protein in rats with induced nephrotic syndrome, resulted from Se-deficient diet (Kang et al., 2019; Fydryk et al., 2003). 
The present study revealed lower levels of PTH, iPTH and vitamin D level in NS patients as compared to the control group. Lower levels of PTH and iPTH might be due to small sample size of the study. NS patients usually suffer from metabolic bone disease which is a side effect of long-term steroid treatment, it had a great effect on the overall disease burden of NS including immunosuppression, osteoporosis, poor growth and notable changes in skin and fat composition (Joyce et al., 2020 and Boraey et al., 2012). Secondary hyperparathyroidism developed in NS patients due to glucocorticoids suppression of calcium intestinal absorption and reduction of calcium reabsorption (Preedy, 2011).

A significant negative correlation was observed between serum zinc and level of PTH in patients with NS. The effect of PTH on plasma zinc concentration in case of chronic renal failure was investigated by Chen et al. (2005). They found that PTH enhanced extra renal zinc disposal and enhances uptake of liver zinc which suggests that the over-secretion of PTH may have a role in Zn deficiency .On the other hand, Kimmel et al. (2001) found that zinc deficiency limits the increase in plasma PTH concentration and the expression of secondary hyperparathyroidism bone disease. The exact mechanism of this effect is not known, but, synthesis, release, metabolism, clearance, and/or action of PTH on cellular level may be affected directly by Zn.

The present study revealed, positive correlations between both of serum $\mathrm{Zn}$ ad $\mathrm{Cu}$ levels and urinary ACR. These positive correlations might be due to small sample size of the study. $\mathrm{Zn} / \mathrm{Alb}$ ratio was significantly higher in NS patients than in healthy controls. An increase in the serum $\mathrm{Zn} / \mathrm{Alb}$ ratio in the presence of proteinuria, indicating a proportionately larger albumin loss (Haque et al., 2017). Another thing which has been observed was that serum $\mathrm{Zn}$ and serum $\mathrm{Cu}$ had positive correlation with each other. Hypoalbuminemia can cause plasma $\mathrm{Zn}$ deficiency, as zinc is bound to albumin in the circulation. $90 \% \mathrm{Cu}$ is bound to ceruloplasmin and $10 \%$ to albumin. Ito et al. (2001) suggested that in nephrotic syndrome the $\mathrm{Cu}$ deficiency was the consequence of urinary losses of ceruloplasmin.

Increased 24 hour urinary protein losses, decreased dietary intake and urinary losses of trace elements were reported as the causes of $\mathrm{Zn}$ and Cu deficiency in NS (Mumtaz et al., 2011).

According to Shah et al. (2008) disturbed tubular function alter reabsorption of filtered aminoacids and trace metals. In the absence of proteinuria, there is urinary losses of $\mathrm{Zn}$ which means that $\mathrm{Zn}$ losses resulted from alteration in renal tubular reabsorption or secretion.

$\mathrm{Zn}$ deficiency reduced renal blood flow and increased renal vascular resistance, which may be resulted from decreased nitric oxide activity due to the presence of increased concentrations of superoxide anions through low SOD activity in the kidneys (Kurihara et al., 2002). Zn deficiency augments tubulointerstitial nephropathy in rats due to an increase in the action of angiotensin II and endothelin (Yanagisawa et al., 1998). Renal function was improved by $\mathrm{Zn}$ supplementation (Sun et al., 2014), it also reduces albumin excretion in patients with diabetic nephropathy (Parham et al., 2008; Khan et al., 2013). Zn has important role in preserving renal function. More studies are needed to explore the association between $\mathrm{Zn}$ and/or $\mathrm{Cu}$ and renal function in humans. A study done by Hamasaki et al. (2016) suggested that serum $\mathrm{Zn} / \mathrm{Cu}$ ratio can be used as a biomarker for renal function.

\section{Conclusion}

Our data showed that serum levels of $\mathrm{Zn}, \mathrm{Cu}$ and Se were lower in children with NS than in healthy children. The negative correlation between serum PTH and low Zn levels might infer a causal relationship. Serum $\mathrm{Zn}$ and $\mathrm{Cu}$ levels were significantly associated with proteinuria in NS patients. According to these results, Supplementation of these trace elements may be considered in patients with NS. Large scale longitudinal researches are needed to assess the beneficial effects of these trace elements supplementation in NS children.

\section{Acknowledgment.}

Thanks to National Research Centre in Egypt for the continuous support.

\section{Conflict of interest}

None 


\section{References}

Afroze, R. Sh., N. M. Khemchand, H.Ch. Saeed, and I. Kh. Shuja, 2014. Zinc Supplement in Reduction of Relapses in Children with Steroid Sensitive Nephrotic Syndrome. Journal of the College of Physicians and Surgeons Pakistan, 24 (2): 110-113.

APHA (American Public Health Association), AWWA (American Water Works Association), and WEF (Water Environment Federation), 2017. Standard Methods for the Examination of water and Wastewater,23 rd ed.(Rice,E.W.,Baird,R.B.,Eaton,A.D.,Clsceri, L.S. eds.)Washington DC.

Arun, S., S. Bhatnagar, S. Menon, S. Saini, P. Hari, and A. Bagga, 2009. Efficacy of zinc supplements in reducing relapses in steroid-sensitive nephrotic syndrome. Pediatric Nephrology, 24(8):15831586.

Bakkaloglu, S.A. and F. Schaefer, 2011. Diseases of the kidney and urinary tract in children. In: Taal MW, Chertow GM, Marsden PA, et al., eds. Brenner and Rector's The Kidney. 9 ${ }^{\text {th }}$ ed. Philadelphia: Saunders, 2622-2643.

Boraey, N.F. and M.M.El-Sonbaty, 2011. Behavioral Problems in Children with Nephrotic Syndrome. J Appl Sci Res., 7(12): 2001-2007.

Boraey, N.F., A. Addosooki, M.A. Mohammad, M.M. El-Sonbaty, S.E.El-Toukhy, 2012. Metabolic Bone Disease in Children with Idiopathic Nephrotic Syndrome. Life Science Journal, 9(4): 75 280.

Chen, S.M., C. Deng, J.F. Iaio, and L.T. HO, 2005. Effects of parathyroid hormone on plasma zinc concentration in rat with chronic renal failure. Chin J. Physiol., 48(2):121-128.

El-Saeed, G.S.M., M.F. Elshamaa, H. Abdelaziz, E.A. Elghoroury, S.M. Abdelrahman, D.A. Abdelhalim, M.H. Ibrahim , E.M. Hassan and M.M. Nabhan, 2018. Vitamin D receptor gene polymorphisms in nephrotic syndrome children. JIPBS, 5 (4): 86-93.

Fydryk, J., M. Olszewska, T. Urasinski, and A. Brodkiewicz, 2003. Serum selenium level and glutathione peroxidase activity in steroid-sensitive nephrotic syndrome. Pediatr Nephrol., 18(10):1063-5.

Fydryk, J., M. Olszewska, T. Urasiński, and A. Brodkiewicz, 2003. Serum selenium level and glutathione peroxidase activity in steroid-sensitive nephrotic syndrome. Pediatr Nephrol.; 18(10):1063-1065. doi:10.1007/s00467-003-1237-7.

Hamasaki, H., Y. Kawashima, and H. Yanai, 2016. Serum $\mathrm{Zn} / \mathrm{Cu}$ ratio is associated with renal function, glycemic control, and metabolic parameters in Japanese patients with and without type 2 diabetes: a cross-sectional study. Frontiers in endocrinology, 15(7):147.

Hamik, W., D. Hilmanto and S. E. Rahayuningsih, 2019. Relationship between serum zinc and homocysteine in children with nephrotic syndrome. Paediatr Indones, 59(2). https://doi.org/10.14238/pi59.2.2019.98-103

Haque, F., M. Hanif and T.R. Choudhury, 2017. Role of Zinc in Patients with Nephrotic Syndrome. J Ped. Nephrology, 5(1): https://doi.org/10.22037/jpn.v5i1.14035.

Hiller, F., L. Oldorff, K. Besselt, and A.P. Kipp, 2015. Differential acute effects of selenomethionine and sodium selenite on the severity of colitis. Nutrients, 7(4):2687-706.

Hossain, M.A., K.P. Deb, M.A. Hossain, K.A. Mannan, G. Mostafa and M.M. Hossain, 2016. Correlation between Serum Cholesterol and Serum Albumin Level in Childhood Nephrotic Syndrome. Urology \& Nephrology Open Access Journal; 3(4):00086

Ito, S., H. Fujita, T. Narita, T. Yaginuma, Y. Kawarada, M. Kawagoe, and T. Sugiyama, 2001. Urinary copper excretion in type 2 diabetic patients with nephropathy. Nephron, 88:307-12.

Joyce, T., P. Rasmussen, N. Melhem, J. Clothier, C. Booth, and M.D. Sinha, 2020. Vitamin and trace element concentrations in infants and children with chronic kidney disease. Pediatr Nephrol., 35(8):1463-1470.

Kang, Y., D. Feng, H.K. Law, et al., 2019. Compositional alterations of gut microbiota in children with primary nephrotic syndrome after initial therapy. BMC Nephrol 20, 434, https://doi.org/10.1186/s12882-019-1615-4).

Khan, M.I., K.U. Siddique, F. Ashfaq, W. Ali, and H.D. Reddy, 2013. Mishra A. Effect of high- dose zinc supplementation with oral hypoglycemic agents on glycemic control and inflammation in type-2 diabetic nephropathy patients. J. Nat. Sci. Biol. Med., 4(2):336-40. 
Kimmel, P.I., C.B. Langman, M.C. Faugere, L.S. Chawla, D.W. Watkins, and H.H. Malluche, 2001. Zinc nutritional status modifies renal osteodystrophy in uraemic rats. Clin Nephrol., 56 (6):445458.

Kumar, D., A. Priyanka, and K. Sh. Indra and Mukesh Vir Singh, 2017. Effect of zinc therapy in remission of pediatric nephrotic syndrome. Int J Contemp Pediatr., (6):2036-2040. DOI: 10.18203/2349-3291.ijcp20174726

Kurihara, N., H. Yanagisawa, M. Sato, C.K. Tien, and O. Wada, 2002. Increased renal vascular resistance in zinc-deficient rats: role of nitric oxide and superoxide. Clin Exp Pharmacol Physiol., 29(12):1096-104.

Manser, W.W.T., 1989. Disease: abnormalities of copper, zinc and magnesium in blood. JPMA. The Journal of the Pakistan Medical Association. https://jpma.org.pk/PdfDownload/5693.

Mumtaz, A., M. Anees, S. Fatima, R. Ahmed, and M. Ibrahim, 2011. Serum zinc and copper levels in nephrotic syndrome patients. Pak J Med Sci., 27(5):1173-6.

NIH, National Institute of Health, 2020. Office of Diatery Supplement. Zn: Fact Sheet for Health Professionals. 2020. https://ods.od.nih.gov/factsheets/Zinc-HealthProfessional/\#disc. Accessed on 12 March.

Parham, M., M. Amini, A. Aminorroaya, E. Heidarian, 2008. Effect of zinc supplementation on microalbuminuria in patients with type 2 diabetes: a double blind, randomized, placebocontrolled, cross-over trial. Rev. Diabet Stud., 5(2):102-9.

Preedy, V.R., editor, 2011. Handbook of growth and growth monitoring in health and disease. Springer Science \& Business Media; Dec 2.

Sasi, A., Sh.Bhatnagar, Sh.Menon, S. Saini, , P. Hari, and A. Bagga, 2009. Efficacy of zinc supplements in reducing relapses in steroid-sensitive nephrotic syndrome. Pediatric nephrology (Berlin, Germany). 24. 1583-6. 10.1007/s00467-009-1170-5.

Shah, K.N., and A.C. Yan, 2008. Acquired zinc deficiency acrodermatitis associated with nephrotic syndrome. Pediatr Dermatol, 25:56-9.

Shreenath, A.P., J. Dooley, 2020. Selenium Deficiency. [Updated 2019 Dec 28]. In: StatPearls [Internet]. Treasure Island (FL): StatPearls Publishing; Available from: https://www.ncbi.nlm.nih.gov/books/NBK482260/

Souberbielle, C., G. Friedlander, and C. Cormier, 2006. Practical considerations in PTH testing. Clin Chim Acta, 366:81-89.

Sun, W., Y. Wang, X. Miao, Y. Wang, L. Zhang, Y. Xin, et al., 2014. Renal improvement by zinc in diabetic mice is associated with glucose metabolism signaling medi-ated by metallothionein and Akt, but not Akt2. Free Radic. Biol. Med., 68:22-34.

Tulpar, S., Z. Gunduz, U. Sahin, P.M. Hakan, I. Dursun, R. Dusunsel, and F. Bastug, 2014. Trace elements in children suffering from idiopathic nephrotic syndrome. Eurasian J Med. Oct; 46(3):187-91. doi: 10.5152/eajm.2014.36. Epub 2014 Jul 8. PMID: 25610323; PMCID: PMC4299852.

Wazir, S.M., and I. Ghobrial, 2017. Copper deficiency, a new triad: anemia, leucopenia, and myeloneuropathy. J Community Hosp Intern Med Perspect., 19; 7(4):265-268.

Yanagisawa, H., M. Nodera, and O. Wada, 1998. Zinc deficiency aggravates tubulointersti-tial nephropathy caused by ureteral obstruction. Biol. Trace Elem. Res., 65(1):1-6. 